\title{
STRATEGI IMPLEMENTASI PEMBANGUNAN ZONA INTEGRITAS PADA KANTOR KEMENTERIAN AGAMA KABUPATEN PEKALONGAN
}

\author{
Ahmad Sirin \\ Kantor Kementerian Agama Kabupaten Pekalongan \\ dewan_06@yahoo.co.id
}

DOI : http://doi.org/10.37730/edutrained.v5i2.156

Diterima: 24 November 2021 | Disetujui: 29 Desember 2021 | Dipublikasikan: 29 Desember 2021

\begin{abstract}
Abstrak
Penelitian ini bertujuan untuk mendeskripsikan dan menganalisis strategi dalam mewujudkan implementasi pembangunan zona integritas sebagai bagian dari program reformasi birokrasi. Penelitian ini menggunakan metode kualitatif deskriptif dengan teknik pengumpulan data melalui wawancara, observasi dan pengumpulan data sekunder berupa data statistik, laporan dan dokumen perundangan. Penentuan informan dengan purposive sampling pada pegawai Kantor Kementerian Agama Kabupaten Pekalongan. Data dianalisis terhadap jawaban yang diwawancarai dengan data sekunder yang diperoleh dan verifikasi keabsahan data dilakukan dengan teknik triangulasi. Hasil penelitian menunjukkan bahwa Strategi Implementasi Pembangunan Zona Integritas dapat dicapai dengan memenuhi semua indikator-indikator komponen pengungkit dan komponen hasil. Indikator tersebut dibuktikan dengan evidence atau Lembar Kerja Evaluasi (LKE) yang akan dinilai oleh Tim Penilai pembangunan zona integritas. Selain itu juga diperlukan strategi berupa Keteladanan Pimpinan, Sumber Daya Manusia, Sarana dan Prasarana, Sosialisasi dan Monitoring dan Evaluasi.
\end{abstract}

Kata Kunci: implementasi, zona integritas, reformasi birokrasi

\begin{abstract}
This study aims to describe and analyze strategies in realizing the implementation of integrity zone development as part of the bureaucratic reform program. This study uses descriptive qualitative methods with data collection techniques through interviews, observation and secondary data collection in the form of statistical data, reports and legal documents. Determination of informants by purposive sampling on employees of the Ministry of Religion of Pekalongan Regency. The data were analyzed against the answers of the interviewees with secondary data obtained and verification of the validity of the data was carried out using triangulation techniques. The results of the study indicate that the Integrity Zone Development Implementation Strategy can be achieved by fulfilling all the indicators of the lever component and the outcome component. These indicators are proven by evidence or Evaluation Worksheets (LKE) which will be assessed by the Assessment Team for the construction of the integrity zone. In addition, a strategy is needed in the form of exemplary leadership, human resources, facilities and infrastructure, socialization and monitoring and evaluation.
\end{abstract}

Keywords: implementation, integrity zone, bureaucratic reform 


\section{PENDAHULUAN}

Persepsi masyarakat terhadap birokrasi di Indonesia masih negatif, karena perilaku pejabat publik yang tidak sesuai dengan apa yang seharusnya dilakukan. Indonesia telah melakukan reformasi birokrasi, namun hingga saat ini masih belum mengalami perubahan (Kadir, 2018). Reformasi birokrasi merupakan salah satu langkah awal untuk melakukan penataan terhadap sistem penyelenggaraan pemerintahan yang baik, efektif dan efisien, sehingga dapat melayani masyarakat secara cepat, tepat, dan profesional (Hanafi \& Harsono, 2020).

Terdapat kendala dalam perjalanan reformasi birokrasi, diantaranya adalah penyalahgunaan wewenang, praktek KKN dan lemahnya pengawasan. Reformasi pelayanan publik harus mampu menjangkau perubahan yang mendasar dalam rutinitas kerja administrasi, budaya birokrasi, dan prosedur kerja instansi pemerintah. Dengan mempertimbangkan isu-isu, tuntutan, kritik dan keluhan masyarakat akan buruknya kualitas pelayanan publik, maka diperlukan adanya reformasi oleh pemerintah dalam mengatur penyediaan jasa pelayanan publik.

Sejalan dengan hal tersebut, Pemerintah telah menerbitkan (Peraturan Presiden RI Nomor 81 Tahun 2010 Tentang Grand Design Reformasi Birokrasi 2010-2025, 2004) yang mengatur tentang pelaksanaan program reformasi birokrasi. Sasaran utama yang ingin dicapai pada peraturan tersebut, adalah peningkatan kapasitas dan akuntabilitas organisasi, pemerintah yang bersih dan bebas KKN, serta peningkatan pelayanan publik.

Grand Design Reformasi Birokrasi 2010-2025 mempunyai makna sebagai sebuah langkah perubahan besar dalam paradigma untuk mengelola pemerintahan Indonesia dalam menghadapi tantangan abad ke-21. Jika berjalan dengan baik maka reformasi birokrasi akan mencapai tujuan yang diharapkan, seperti mengurangi dan akhirnya menghilangkan setiap penyalahgunaan kewenangan publik oleh pejabat di instansi yang bersangkutan, menjadikan negara yang memiliki mostimproved bureaucracy, meningkatkan mutu pelayanan kepada masyarakat, meningkatkan mutu dalam perumusan dan pelaksanaan kebijakan/program instansi pemerintahan, meningkatkan efisiensi dalam pelaksanaan semua tugas organisasi; menjadikan birokrasi Indonesia antisipatif, proaktif, dan efektif dalam menghadapi globalisasi dan dinamika perubahan lingkungan strategis (Peraturan Presiden RI Nomor 81 Tahun 2010 Tentang Grand Design Reformasi Birokrasi 2010-2025, 2004).

Pemerintah telah melakukan akselerasi dalam pencapaian sasaran hasil tersebut, dengan membangun pilot project pelaksanaan reformasi birokrasi yang dapat menjadi percontohan penerapan pada unit-unit kerja lainnya. Unit kerja harus secara konkret melaksanakan program reformasi birokrasi melalui upaya pembangunan Zona Integritas. Integritas dalam melayani publik harus diciptakan dalam lingkungan instansi pemerintah (Hanafi \& Harsono, 2020).

Dalam rangka memberikan apresiasi kepada unit kerja yang memiliki komitmen terhadap pencegahan korupsi, Menteri PAN dan RB menerbitkan Permenpan dan RB Nomor 52 tahun 2014 tentang Pedoman Umum Pembangunan Zona Integritas Menuju Wilayah Bebas dari Korupsi. Peraturan tersebut sebagai pedoman umum bagi pejabat di lingkungan Kementerian/Lembaga dan Pemerintah Daerah (K/L/Pemda) dalam rangka Pembangunan Zona Integritas Menuju Wilayah Bebas dari Korupsi. K/L/Pemda yang telah mencanangkan kesiapan/kesanggupan berpredikat ZI mewujudkan komitmen pencegahan korupsi melalui pelaksanaan kegiatan pencegahan korupsi dalam bentuk yang lebih nyata secara terpadu dan disesuaikan dengan kebutuhan $\mathrm{K} / \mathrm{L} /$ Pemda yang bersangkutan (Kadir, 2018). 
Konsep Zona Integritas sebenarnya berasal dari konsep island of integrity. Island of integrity atau pulau integritas biasa digunakan oleh pemerintah maupun NGO untuk menunjukkan semangatnya dalam pemberantasan dan pencegahan tindak pidana korupsi. Transparansi Internasional Indonesia (TII) mengartikan Island of integrity sebagai konsep "kepulauan" yang bisa bermakna institusi pemerintah/badan pemerintahan yang memiliki dan menerapkan konsepsi Sistem Integritas Nasional (National Integrity System/NIS) sehingga kewibawaan dan integritas institusi tersebut mampu mewujudkan transparansi, akuntabilitas dan membuka ruang partisipasi masyarakat secara luas sehingga senantiasa terjaga dari praktek KKN dan praktek tercela lainnya (Kadir, 2018).

Kementerian Agama sebagaimana diatur dalam (Peraturan Presiden RI Nomor 68 Tahun 2019 Tentang Organisasi Kementerian Negara, 2019)

Tabel 1

Satuan Kerja Kementerian Agama Berpredikat WBK dan WBBM

\begin{tabular}{clcc}
\hline No & \multicolumn{1}{c}{ Nama Satuan Kerja } & Predikat & Tahun \\
\hline 1. & Kankemenag Kab. Musi Banyuasin & WBK & 2017 \\
2. & UIN Banjarmasin & WBK & 2017 \\
3. & Kankemenag Kab. Karangasem Prov. Bali & WBK & 2018 \\
4. & Kankemenag Kota Denpasar Prov. Bali & WBK & 2018 \\
5. & Kankemenag Kota Yogyakarta Prov. Yogyakarya & WBK & 2018 \\
6. & Kanwil Kemenag Prov. Bali & WBK & 2019 \\
7. & Kankemenag Kab. Bantul Prov. Yogyakarta & WBK & 2019 \\
8. & Balai Diklat Keagamaan Semarang Prov. Jawa & WBK & 2019 \\
& Tengah & & \\
9. & Kankemenag Kota Singkawang Prov. Kalimantan & WBK & 2019 \\
& Barat & & \\
10. & Kankemenag Kab. Ogan Komering Ilir Prov. & WBK & 2019 \\
11. & Sumatera Selatan Salatiga Prov. Jawa Tengah & WBK & 2020 \\
12. & Kankemenag Kota Denpasar Prov. Bali & WBBM & 2020 \\
13. & Kankemenag Kota Yogyakarta Prov. Yogyakarta & WBBM & 2020 \\
\hline
\end{tabular}

Sumber: itjen.kemenag.go.id, 2020

merupakan Kementerian yang mempunyai tugas menyelenggarakan urusan pemerintahan di bidang agama untuk membantu Presiden dalam menyelenggarakan pemerintahan negara. Dalam menjalankan tugas dan fungsi di bidang agama dan keagamaan, Kementerian Agama melaksanakan reformasi birokrasi dengan menetapkan pembangunan Zona Integritas menuju Wilayah Bebas dari Korupsi (WBK) dan Wilayah Birokrasi Bersih dan Melayani (WBBM).

Dari jumlah satuan kerja Kementerian Agama sebanyak 4.593, baru 54 satuan kerja yang lolos uji Tim Penilai Internal dari sebanyak 84 satuan kerja yang diusulkan (Indah, 2021). Sampai dengan tahun 2021 baru 11 satuan kerja yang memperoleh predikat Wilayah Bebas dari Korupsi (WBK) dan 2 satuan kerja memperoleh predikat Wilayah Birokrasi Bersih Melayani (WBBM) . Satuan kerja tersebut dapat dilihat pada tabel berikut: 
Kantor Kementerian Agama Kabupaten Pekalongan pada tahun 2021 menjadi salah satu pilot project pembangunan Zona Integritas menuju Wilayah Bebas dari Korupsi di lingkungan Kantor Wilayah Kementerian Agama Provinsi Jawa Tengah. Pencanangan Zona Integritas sudah dilaksanakan pada tahun 2017 dengan penandatanganan pakta integritas, kemudian berlanjut pada tahun 2020 ditetapkan menjadi satuan kerja pilot project. Pada Tahun 2021 sudah melalui proses penilaian mandiri, kemudian penilaian oleh Sekretriat Jenderal Kementerian Agama, kemudian penilaian oleh Tim Penilai Internal dari Inspektorat Jenderal Kementerian Agama dan terakhir penilaian oleh Tim Penilai Kementerian PAN/RB.

Satuan kerja Kementerian Agama yang memperoleh predikat WBK baru sebesar 0,239 persen, sedangkan yang memperoleh predikat WBBM baru sebesar 0,043 persen. Kecilnya prosentase tersebut menjadi permasalahan tersendiri bagi Kementerian Agama.

Faktor penting pada implementasi pembangunan zona integritas diantaranya Perubahan pola pikir dan budaya kerja dari Aparatur Sipil Negara (ASN). Hal ini diharapkan melahirkan pencegahan tindakan korupsi dan pelayanan publik yang prima. faktor ini yang menjadi permasalahan pada Kantor Kementerian Agama Kabupaten Pekalongan dalam proses implementasi pembangunan zona integritas. Internalisasi nilai-nilai zona integritas bagi pegawai belum optimal.

Faktor kepemimpinan juga menjadi permasalahan dalam implementasi pembangunan zona integritas. Baik buruknya suatu organisasi dipengaruhi oleh seorang pemimpin. Dengan kepemimpinan yang baik, maka permasalahan dan tantangan yang terjadi dalam suatu organisasi pemerintahan dapat terselesaikan dengan baik. Sebaliknya kepemimpinan yang buruk, hal-hal yang berkaitan dengan patologi birokrasi (maladministrasi, korupsi, kolusi, dan nepotisme) akan semakin merajalela. Oleh karenanya, faktor kepemimpinan bisa menjadi kunci keberhasilan atau penyebab kemunduran.

Implementasi pembangunan zona integritas tidak hanya pemenuhan evidence atau Lembar Kerja Evaluasi (LKE) yang memuat indikator pengungkit dan indikator komponen hasil. Faktor perubahan pola pikir dan budaya kerja dari ASN dan faktor kepemimpinan adalah hal penting dan menjadi permasalahan utama pada penelitian ini.

Berdasarkan hasil penelitian terdahulu diantaranya, (Ari Cahyono \& Raka Suardana, 2021), (Gani, 2019), (Julia et al., 2019), (Mosepa, H Andri, Agus Abdur Rahman, 2018), (Widarti \& Madalina, 2018), (Wilujeng \& Pramudyastuti, 2020), menyatakan bahwa faktor yang menghambat implementasi pembangunan zona integritas diantaranya adalah sosialisasi, sumber daya manusia, komitmen pegawai, anggaran, sarana dan prasarana, struktur organisasi dan mekanisme penilaian yang rumit.

Merujuk pada berbagai ulasan hasil penelitian sebelumnya terdapat faktor yang mempengaruhi implementasi pembangunan zona integritas. Oleh karena itu, tujuan penelitian ini adalah untuk mendeskripsikan dan menganalisis Strategi Implementasi Pembangunan Zona Integritas pada Kantor Kementerian Agama Kabupaten Pekalongan.

\section{KAJIAN PUSTAKA}

\section{Implementasi Kebijakan}

Implementasi kebijakan pada dasarnya adalah sebuah cara agar suatu kebijakan mencapai tujuannya. Studi implementasi kebijakan dimaksudkan untuk memahami fenomena implementasi kebijakan, seperti mengapa suatu kebijakan gagal diimplementasikan, mengapa suatu kebijakan memiliki tingkat keberhasilan yang berbeda-beda, mengapa suatu kebijakan lebih mudah diimplementasikan dibanding dengan 
kebijakan lainnya, atau mengapa sasaran kebijakan mempengaruhi keberhasilan implementasi kebijakan (Gani, 2019).

Menurut Van Meter dan Van Horn dalam (Gani, 2019), implementasi kebijakan sebagai tindakan-tindakan yang dilakukan baik oleh individu atau pejabat atau kelompok pemerintah atau swasta yang diarahkan pada tercapainya tujuan yang telah digariskan dalam keputusan kebijakan. George C. Edward III (1980) dalam (Gani, 2019), menjelaskan beberapa variabel yang mempengaruhi efektivitas implementasi kebijakan, yakni: (1) komunikasi, (2) sumberdaya, (3) disposisi, dan (4) struktur birokrasi.

Empat faktor tersebut, memiliki pengaruh terhadap implementasi kebijakan publik. Faktor komunikasi, berpengaruh dalam menciptakan pengertian atau pemahaman yang sama bagi pelaku kebijakan, yang kemudian berpengaruh pada sikap, tindakan ataupun perilaku. Faktor sumber daya, adalah faktor kunci bagi efektivitas pelaksanaan kebijakan, seperti manusia, dan anggaran. Faktor disposisi atau sikap pelaksana, berkaitan dengan komitmen dan kepatuhan para pelaksana dalam melaksanakan kebijakan yang telah ditetapkan. Sedangkan, faktor struktur birokrasi berkenaan dengan pembagian kerja, wewenang dan tanggung jawab.

Berdasarkan uraian di atas, penelitian ini merujuk pada teori implementasi kebijakan yang dikemukakan oleh George C. Edward III.

\section{Zona Integritas (ZI), Wilayah Bebas dari Korupsi (WBK), Wilayah Birokrasi Bersih dan Melayani (WBBM)}

Menurut (Peraturan Menteri Pendayagunaan Aparatur Negara dan Reformasi Nomor 52 Tahun 2014 Tentang Pedoman Pembangunan Zona Integritas Menuju WBK, 2014), Zona Integritas (ZI) merupakan predikat yang diberikan kepada instansi pemerintah di mana pimpinan dan jajarannya mempunyai komitmen untuk mewujudkan WBK/WBBM melalui reformasi birokrasi, khususnya dalam hal pencegahan korupsi dan peningkatan kualitas pelayanan publik.

Dalam membangun Zona Integritas, pimpinan instansi pemerintah menetapkan satu atau beberapa unit kerja yang diusulkan sebagai Wilayah Bebas Korupsi/Wilayah Birokrasi Bersih dan Melayani. Pemilihan unit kerja yang diusulkan sebagai WBK/WBBM memperhatikan beberapa syarat yang telah ditetapkan, yaitu: 1) Dianggap sebagai unit yang penting/strategis dalam melakukan pelayanan publik; 2) Mengelola sumber daya yang cukup besar, serta 3) Memiliki tingkat keberhasilan Reformasi Birokrasi yang cukup tinggi.

Proses pemilihan unit kerja yang berpotensi sebagai Zona Integritas dilakukan dengan membentuk kelompok kerja/tim untuk melakukan identifikasi terhadap unit kerja yang berpotensi sebagai unit kerja berpredikat menuju WBK/WBBM oleh pimpinan instansi. Setelah melakukan identifikasi, kelompok kerja/tim mengusulkan unit kerja kepada pimpinan instansi untuk ditetapkan sebagai calon unit kerja berpredikat Zona Integritas menuju WBK/WBBM. Selanjutnya dilakukan penilaian mandiri (self assessment) oleh Tim Penilai Internal (TPI). Setelah melakukan penilaian, TPI melaporkan kepada Pimpinan instansi tentang unit yang akan diusulkan ke Kementerian Pendayagunaan Aparatur Negara dan Reformasi Birokrasi sebagai unit kerja berpredikat Menuju WBK/WBBM. Apabila unit kerja yang diusulkan memenuhi syarat sebagai Zona Integritas Menuju WBK/WBBM maka langkah selanjutnya adalah penetapan.

Wilayah Bebas dari Korupsi (WBK) adalah predikat yang diberikan kepada suatu unit kerja yang memenuhi sebagian besar manajemen perubahan, penataan tatalaksana, penataan sistem manajemen SDM, penguatan pengawasan, dan penguatan akuntabilitas kinerja.

Wilayah Birokrasi Bersih dan Melayani (WBBM) adalah predikat yang diberikan kepada suatu unit kerja yang 
memenuhi sebagian besar kelima program pada WBK di atas ditambah dengan program penguatan kualitas pelayanan publik.

\section{Penilaian Pembangunan Zona Integritas}

Berdasarkan (Peraturan Menteri Pendayagunaan Aparatur Negara dan Reformasi Nomor 52 Tahun 2014 Tentang Pedoman Pembangunan Zona Integritas Menuju WBK, 2014), terdapat dua jenis komponen yang harus dibangun dalam unit kerja terpilih, yaitu komponen pengungkit dan komponen hasil. Komponen pengungkit merupakan komponen yang menjadi penentu pencapaian sasaran hasil pembangunan zona integritas menuju WBK/WBBM. Komponen pengungkit meliputi manajemen perubahan, penataan tata laksana, penataan sistem manajemen sumber daya manusia, penguatan akuntabilitas kinerja, penguatan pengawasan, dan penguatan kualitas pelayanan publik.

Komponen hasil merupakan komponen yang menjadi penentu pencapaian program Reformasi Birokrasi dan penyelenggaraan Good Governance. Komponen hasil meliputi pemerintahan yang bersih dan bebas KKN, serta peningkatan kualitas pelayanan publik.

Penilaian terhadap komponen pengungkit (60\%) dan komponen hasil (40\%), dengan perincian sebagai berikut:

a. Komponen pengungkit dengan bobot $60 \%$ yang terbagi atas, manajemen perubahan $5 \%$, penataan tata laksana $5 \%$, penataan sistem manajemen sumber daya manusia $15 \%$, penguatan akuntabilitas kinerja $10 \%$, penguatan pengawasan $15 \%$ dan penguatan kualitas pelayanan publik $10 \%$.

b. Komponen hasil dengan bobot $40 \%$ yang terbagi atas, terwujudnya pemerintahan yang bersih dan bebas KKN 20\%, dan terwujudnya peningkatan kualitas pelayanan publik kepada masyarakat $20 \%$.

Untuk mendapatkan predikat menuju WBK, unit kerja harus memenuhi syarat nilai minimal 75 , sedangkan predikat WBBM nilai minimal yang harus dipenuhi adalah 85 untuk total komponen pengungkit dan komponen hasil.

\section{Indikator Implementasi Pembangunan Zona Integritas}

Berdasarkan Peraturan Menteri Pendayagunaan Aparatur Negara dan Reformasi Birokrasi Nomor 52 Tahun 2014, penilaian terhadap setiap program dalam komponen pengungkit dan komponen hasil diukur melalui indikatorindikator yang dipandang mewakili program tersebut. Sehingga dengan menilai indikator tersebut diharapkan dapat memberikan gambaran pencapaian upaya yang berdampak pada pencapaian sasaran.

1. Manajemen Perubahan
a. Penyusunan Tim Kerja
b. Dokumen Rencana Pembangunan Zona Integritas
c. Pemantauan dan Evaluasi Pembangunan Zona Integritas
d. Perubahan Pola Pikir dan Budaya Kerja

2. Penataan Tata Laksana
a. Prosedur Operasional tetap (SOP) Kegiatan Utama
b. E-Office
c. Keterbukaan Informasi Publik

3. Penataan Sistem Manajemen Sumber Daya Manusia

a. Perencanaan Kebutuhan Pegawai sesuai dengan Kebutuhan Organisasi

b. Pola Mutasi Internal Pengukuran

c. Pengembangan Pegawai Berbasis Kompetensi Pengukuran

d. Penetapan Kinerja Individu

e. Penegakan Aturan Disiplin/Kode Etik/Kode Perilaku Pegawai Pengukuran

f. Sistem Informasi Kepegawaian

4. Penguatan Akuntabilitas Kinerja
a. Keterlibatan Pimpinan
b. Pengelolaan Akuntabilitas Kinerja

5. Penguatan Pengawasan
a. Pengendalian Gratifikasi
b. Penerapan Sistem Pengawasan Internal Pemerintah (SPIP)
c. Pengaduan Masyarakat 
d. Whistle Blowing System

e. Penanganan Benturan Kepentingan

6. Penguatan Kualitas Pelayanan Publik

a. Standar Pelayanan

b. Budaya Pelayanan Prima

c. Penilaian Kepuasan Terhadap Pelayanan

\section{METODE PENELITIAN}

Jenis penelitian ini adalah penelitian kulitatif deskriptif, yaitu penelitian yang memanfaatkan data kualitatif dan dijabarkan secara deskriptif.

Teknik menentukan informan penelitian menggunakan metode purposive sampling, yaitu teknik pengambilan sumber data dengan pertimbangan tertentu (Sugiyono, 2019). Kriteria pemilihan informan dalam penelitian ini adalah pegawai yang secara langsung terlibat dalam implementasi pembangunan zona integritas pada Kantor Kementerian Agama Kabupaten Pekalongan, meliputi: Kepala Subbag Tata Usaha; Tim Pembangunan Zona Integritas; Agen Perubahan; Pegawai.

Teknik pengumpulan data melalui wawancara, observasi dan pengumpulan data sekunder berupa data statistik, laporan dan dokumen perundangan. data yang diperoleh selanjutnya dianalisis secara sistematis dengan langkah reduksi data, penyajian data dan penarikan keimpulan dan verifikasi.

Keabsahan data diolah dengan menggunakan teknik triangulasi, yaitu teknik yang bersifat menggabungkan dari berbagai teknik pengumpulan data dan sumber data yang telah ada (Sugiyono, 2019). Penelitian ini menggunakan teknik Triangulasi sumber data, yaitu menggali kebenaran informasi tertentu dengan menggunakan berbagai sumber data seperti dokumen, arsip, hasil wawancara, hasil observasi atau juga dengan mewawancarai lebih dari satu subjek yang dianggap memiliki sudut pandang yang berbeda.

Wawancara secara bebas dilakukan kepada pegawai yang terlibat dalam Tim Pembangunan Zona Integritas Kantor Kementerian Agama Kabupaten
Pekalongan, yaitu Bidang Manajemen Perubahan, Penataan Tatalaksana, Penataan Manajemen SDM, Penguatan Akuntabilitas Kinerja, Penguatan Pengawasan, dan Peningkatan Kualitas Pelayanan Publik. Hasil wawancara kemudian dikombinasikan dengan obeservasi dan studi dokumen, dalam hal ini dokumen Lembar Kerja Evaluasi (LKE).

Dalam penelitian ini peneliti sebagai Tim Pembangunan Zona Integritas area penguatan pengawasan. Sehingga peneliti tidak hanya berperan sebagai pengambil dan pengolah data, akan tetapi menjadi teman dari informan atau subyek penelitian. Keterlibatan peneliti secara langsung dan aktif dengan informan dan sumber data lainnya dapat dikatakan sebagai pengamat penuh. Sehingga hasil penelitian akan lebih valid adan akurat.

\section{HASIL PENELITIAN DAN PEMBAHASAN}

\section{Hasil Penelitian}

\section{A. Implementasi Pembangunan Zona Integritas pada Kantor Kementerian Agama Kabupaten Pekalongan}

Implementasi Pembangunan Zona Integritas pada Kantor Kementerian Agama Kabupaten Pekalongan secara resmi ditunjuk oleh Kantor Wilayah Kementerian Agama Provinsi Jawa Tengah menjadi pilot project tahun 2020. Meski pencanangan pembengunan Zona Integritas sudah dimulai pada tahun 2017 dengan penandatanganan pakta integritas bagi pegawai.

Menurut Muqodam (2021) bahwa implementasi pembangunan zona integritas sudah mengikuti ketentuan yang ada. Evaluasi dari tim penilai internal sudah diupayakan untuk dilengkapi sesuai dengan indikator pada Lembar Kerja Evaluasi (LKE). Perubahan sarana dan prasarana juga sudah menyesuaikan dengan hasil evaluasi tim penilai internal. Untuk sosialisasi diharapkan seluruh pegawai bisa ikut menyampaikan melalui media sosial, agar 
gaung zona integritas tersampaikan kepada masyarakat luas.

Berdasarkan wawancara dengan Sujud (2021) menyatakan bahwa implementasi pembangunan zona integritas masih sebatas pemenuhan evidence atau Lembar Kerja Evaluasi (LKE). Penguatan zona integritas belum menyentuh pada perubahan mind-set dan budaya kerja pegawai.

Senada dengan pernyataan Sujud (2021), Suningsih (2021), Raharjo (2021), Baroroh (2021), Purwaningsih (2021) menyatakan bahwa implementasi zona integritas hanya sebatas memenuhi evidence saja. Perubahan mind-set pada zona integritas dari level pimpinan sampai pegawai belum optimal, masih sebatas slogan saja belum menguat pada perilaku.

Implementasi Pembangunan Zona Integritas pada Kantor Kementerian Agama Kabupaten Pekalongan dapat diuraikan sebagai berikut:

1. Manajemen Perubahan

a. Peningkatan Komitmen Seluruh Jajaran Pimpinan dan Pegawai

- Tim kerja telah terbentuk dengan prosedur yang jelas dan mewakili seluruh unsur;

- Rencana kerja dengan targettarget yang relevan dengan tujuan pembangunan ZI terlaksana dan dipublikasikan.

b. Terjadinya Perubahan Pola Pikir Dan Budaya

- Semua anggota terlibat dalam pembangunan ZI;

- Agen perubahan berkontribusi terhadap perubahan;

- Hasil monev terlihat berjalannya pembangunan ZI dengan baik.

c. Menurunnya Resiko Kegagalan Yang Disebabkan Kemungkinan Timbulnya Resistensi Terhadap Perubahan

- Komitmen bersama melalui penandatanganan Pakta Integritas;

- Sosialisasi \& internalisasi rencana kerja, kode etik ASN, budaya melayani, anti korupsi, benturan kepentingan, masyarakat, WBS, SPIP dan pelayanan prima melalui apel pagi, pembinaan pegawai, dan terintegrasi dengan berbagai kegiatan lainnya.

2. Penataan Tata Laksana

a. Peningkatan Penggunaan Teknologi Informasi dalam Proses Penyelenggaraan Manajemen Pemerintahan

- Sistem pengukuran kinerja berupa e-MPA, e-Monev, e-Smart DJA, Simak BMN, SAIBA;

- Operasionalisasi manajemen SDM menggunakan teknologi informasi berupa SIMPEG;

- Pelayanan kepada publik menggunakan teknologi informasi berupa SIMKAHWEB, SISKOHAT, dan SIMPATIKA.

b. Peningkatan Efisiensi dan Efektivitas Proses Manajemen Pemerintahan

- Menerapkan SOP mengacu pada peta proses bisnis \& dievaluasi;

- Memiliki Tim Pejabat Pengelola Informasi Publik (PPID) yang menyampaikan informasi ke publik melalui web, Youtube, facebook dll yang memungkinkan publik dapat mengakses informasi dengan mudah ;

- Manajemen berbasis IT dan inovasi yang dikembangkan membantu bagi pemangku kepentingan dan publik untuk lebih mudah, cepat, efektif dan efisien mendapatkan pelayanan.

c. Peningkatan Kinerja

- Komunikasi dengan masyarakat/stakeholder melalui pengelolaan efektifitas media, dapat menghindari potensi terjadinya penyimpangan;

- Penggunaan IT dalam proses penyelenggaraan manajemen telah dirasakan manfaatnya yaitu cepat, jelas, mudah dan transparan dan hal ini secara otomatis sebagai upaya menghindari gratifikasi, suap dan kolusi, disamping akan 
berdampak pada peningkatan kualitas pelayanan publik dan kinerja unit.

3. Penataan Sistem Manajemen Sumber Daya Manusia

a. Peningkatan Ketaatan Terhadap Pengelolaan SDM

- Ketaatan dan komitmen seluruh jajaran pimpinan dan pegawai terhadap penggunaan presensi sidik jari, SIMPEG, dan sistem laporan kinerja;

- Mengimplementasikan seluruh aturan disiplin dan/atau kode etik yang ditetapkan.

b. Peningkatan Transparansi dan Akuntabilitas Pengelolaan SDM

- Kebutuhan pegawai dan mutasi disusun mengacu kepada ANJAB dan ABK;

- Data kepegawaian dapat diakses oleh pegawai \& dimutakhirkan;

- Pola mutasi dilakukan sesuai regulasi dan merit sistem.

c. Peningkatan Disiplin SDM

- Pegawai memperoleh kesempatan yang sama untuk mengikuti diklat/ pengembangan kompetensi lainnya;

- Penetapan kinerja individu terkait dengan kinerja organisasi dan perjanjian kinerja selaras dengan sasaran kinerja pegawai (SKP);

- Disiplin pegawai meningkat dengan penerapan presensi menggunakan IT.

d. Peningkatan Efektivitas Manajemen dan Profesionalisme SDM

- Kesempatan mengikuti diklat/pelatihan pegawai berdampak peningkatan kompetensi, profesionalitas pegawai dan berkontribusi positif terhadap capaian kinerja;

- Monev secara berkala menjadi bagian penting dari manajemen SDM yang berdampak positif terhadap meningkatnya akuntabilitas kinerja, penyusunan laporan kinerja tepat waktu dan pelaporan kinerja telah memberikan informasi tentang kinerja.

4. Penguatan Akuntabilitas Kinerja

a. Peningkatan Kinerja Instansi

- Keterlibatan pimpinan dalam penyusunan perencanaan, penyusunan perjanjian kinerja berdampak positif terhadap peningkatan kinerja;

- Kapasitas SDM yang berkompeten dalam mengelola akuntabilitas memberikan manfaat pada peningkatan kinerja, capaian penyerapan anggaran setiap bulannya sesuai target.

- Memiliki dokumen perencanaan lengkap DIPA. Renstra, RKAKL, RKT dan perencanaan telah berorientasi hasil;

- Kantor Kementerian Agama Kab. Pekalongan melaksanakan evaluasi kinerja dan anggaran setiap triwulan menjadi dasar untuk optimalisasi peningkatan kinerja instansi.

b. Peningkatan Akuntabilitas

- Upaya peningkatan kapasitas SDM yang menangani akuntabilitas kinerja yang didukung teknologi informasi mampu memberikan manfaat dalam pencapaian kinerja dan terhindar dari penyelewengan (tindakan korupsi);

- Memiliki Indikator Kinerja Utama (IKU) yang indikatornya telah SMART mampu memberikan manfaat untuk mendapatkan ukuran sejauh mana keberhasilan dan pencapaian yang telah diraih pada tahun terakhir. Hal ini akan bermanfaat sebagai acuan untuk meningkatkan kinerja pada tahun berikutnya;

- Mendapatkan beberapa pengakuan/penghargaan dari KPPN presentasi dari Kementerian Keuangan.

5. Penguatan Pengawasan a. Pengendalian Gratifikasi 
- Tersosialisasinya Pengendalian Gratifikasi melalui media sosial dan pembinaan pegawai

- Terdokumennya laporan

b. Penerapan Sistem Pengawasan Internal Pemerintah (SPIP)

- Terbentuknya Satgas SPIP

- Tersusunnya matrik peta risiko

- Terlaksananya pengendalian resiko

- Tersosialisinya Media Informasi SPIP

c. Pengaduan Masyarakat

- Tersedianya kontak Pengaduan Masyarakat

d. Whistle Blowing System

- Terlaksananya Sosialisasi WBS internal

e. Penanganan Benturan Kepentingan

- Terlaksananya Pemetaan Benturan Kepentingan

- Implementasi Penanganan Benturan Kepentingan

- Terlaksananya Tindak lanjut Benturan Kepentingan

- Terdokumennya Evaluasi benturan kepentingan

6. Penguatan Kualitas Pelayanan Publik

a. Standar Pelayanan

- Tersusunnya standar layanan pelatihan

- Terciptanya maklumat layanan

- Tersusunnya SOP layanan

- Terlaksananya review layanan dan SOP

b. Budaya Pelayanan Prima

- Terlaksanannya pelatihan budaya layanan prima

- Tersosialisasinya budaya layanan prima dalam media sosial

- Terlaksananya pemberian reward dan punishment

- Terciptanya Inovasi Layanan

c. Penilaian Kepuasan Terhadap

Pelayanan

- Terlaksanannya survey kepuasan masyarakat

- Terdokumennya hasil survey kepuasan masyarakat
7. Inovasi Kantor Kementerian Agama Kabupaten Pekalonagan

a. Tagline SIMPATIK, Simpel, Moderat, Pasti dan Menarik

b. KUAT RAGA, Kerukunan dan Penguatan Moderasi Beragama

c. PEKA, Peduli Kepada Sesama

d. BERIBADAH, Bersih - Bersih Rumah Ibadah

e. BICARA, Bincang-Bincang Antar Umat Beragama

f. CERITA, Ceramah Toleransi Beragama

g. KAPTEN, merupakan portal informasi untuk mempermudah masyarakat dalam mengakses layanan dan informasi yang diberikan Kantor Kemenag Kabupaten Pekalongan. Selain berisi informasi untuk masyarakat, juga berisi daftar aplikasi yang sering digunakan oleh pegawai di lingkungan Kantor Kementerian Agama Kabupaten Pekalogan.

h. SIPECUT, merupakan sebuah inovasi sebagai upaya memangkas proses birokrasi pengajuan cuti pegawai. Pegawai dapat mengajukan permohonan cuti melalui aplikasi, kemudian atasan dapat menyetujui atau menolak permohonan izin cuti yang diajukan oleh pegawai. Petugas admin aplikasi bertugas memverifikasi dan validasi berkas permohonan izin cuti pegawai.

i. KPSS, berisi daftar layanan Kementerian Agama Kabupaten Pekalongan yang dapat diakses langsung oleh masyarakat dengan mengedepankan pelayanan yang bersifat mandiri yaitu pengguna dapat memilih, mengunggah (upload) dokumen, melacak permohonan layanan dan memberikan peringkat pada pelayanan secara mandiri.

\section{B. Penilaian Pembangunan Zona Integritas pada Kementerian Agama Kabupaten Pekalongan}

Setelah ditunjuk menjadi pilot project, Kantor Kementerian Agama Kabupaten 
Pekalongan langsung mengikuti tahapan penilaian. Dimulai dari penilaian mandiri memperoleh nilai 91,84 . Perolehan nilai mandiri tersebut menentukan untuk mengikuti tahapan penilaian berikutnya dari Tim Penilai Internal Inspektorat Jenderal Kementerian Agama. Pada tahapan tersebut diperoleh nilai 87,88.

Setelah dinyatakan lolos pada tahap penilaian internal, kemudian mengikuti tahapan penilaian berikutnya dari Tim Penilai Eksternal, yaitu Kementerian PAN/RB. Pada tahap ini tidak mudah karena harus menyusun survey kepuasan layanan masyarakat. Tim Penilai Eksternal telah melakukan penilaian Kantor Kementerian Agama Kabupaten Pekalongan pada 28 Oktober 2021.

\section{Temuan Penelitian}

Implementasi pembangunan zona integritas pada Kantor Kementerian Agama sudah pada tahap penilaian eksternal. Ada beberapa temuan penelitian yang dapat diuraikan sebagai berikut:

1. Area Manajemen Perubahan

Pada area manajemen perubahan, target yang ingin dicapai dalam program ini seperti meningkatnya komitmen seluruh jajaran pimpinan dan pegawai dan terjadinya perubahan pola pikir dan budaya kerja belum optimal.

Komitmen dan perubahan pola pikir dan budaya kerja hanya pada sebagian pimpinan dan anggota tim. Role model pimpinan juga belum berperan dalam implementasi pembangunan zona integritas.

2. Area Penataan SDM

Pada area penataan SDM, target yang ingin dicapai dalam program ini seperti meningkatnya efektivitas manajemen SDM belum optimal. Hal ini ditandai dengan masih terdapat pegawai yang pembagian kerja belum proporsional.

3. Area Penguatan Pengawasan

Pada area penguatan pengawasan, target yang ingin dicapai dalam program ini seperti menurunnya tingkat penyalahgunaan wewenang belum optimal. Hal ini ditandai dengan pengendalian gratifikasi belum terlaksana dengan baik.

4. Monitoring dan Evaluasi

Monitoring dan evaluasi belum dilaksanakan untuk masing-masing area. Implementasi pembangunan zona integritas masih pada pemenuhan dokumen lembar kerja evaluasi.

\section{Pembahasan}

\section{Strategi \\ Implementasi \\ Pembangunan Zona Integritas pada Kantor Kementerian Agama Kabupaten Pekalongan}

Berdasarkan hasil penelitian terdahulu diantaranya, (Ari Cahyono \& Raka Suardana, 2021), (Gani, 2019), (Julia et al., 2019), (Mosepa, H Andri, Agus Abdur Rahman, 2018), (Widarti \& Madalina, 2018), (Wilujeng \& Pramudyastuti, 2020), menyatakan bahwa faktor yang menghambat implementasi pembangunan zona integritas diantaranya adalah sosialisasi, sumber daya manusia, komitmen pegawai, anggaran, sarana dan prasarana, struktur organisasi dan mekanisme penilaian yang rumit.

Korelasi temuan penelitian dengan teori Edward III bahwa implementasi kebijakan publik dipengaruhi oleh faktor sebagai berikut:

1. Komunikasi

Faktor komunikasi atau sosialisasi terhadap implementasi pembangunan zona integritas sudah berjalan dengan baik. Komunikasi antara pimpinan dengan pegawai disampaikan dalam setiap kegiatan. Begitu pula sosialisasi sudah diinformasikan pada media yang ada baik media offline maupun online.

Masalah lain timbul dari faktor komunikasi adalah esensi yang disampaikan tidak bisa efektif karena tidak dibarengi dengan keteladanan pimpinan. Role model pimpinan yang menjadi teladan bagi pegawai akan lebih efektif dalam 
mengkomunikasikan implementasi kebijakan.

2. Sumber Daya

Faktor sumber daya meliputi manusia dan anggaran penting dalam implementasi kebijakan. Faktor sumber daya manusia perlu perhatian lebih pada implementasi pembangunan zona integritas. SDM merupakan aktor kebijakan, maka penataan SDM perlu diefektifkan sesuai dengan pemetaan yang dilakukan.

Sumber daya anggaran memang terbatas. Namun mengikuti arahan Kepala Kantor Wilayah Kementerian Agama Provinsi Jawa Tengah, bahwa untuk mensukseskan program Kementerian Agama tidak bisa berjalan sendiri, harus kolaborasi dengan satuan kerja lain, termasuk kolaborasi anggaran. Kolaborasi anggaran tersebut digunakan untuk memenuhi sarana dan prasarana yang menunjang implementasi kebijakan.

3. Disposisi

Faktor disposisi berkaitan dengan komitmen dan kepatuhan para pelaksana dalam melaksanakan kebijakan yang telah ditetapkan. Komitmen ini penting dan menjadi hambatan dalam implementasi pembangunan zona integritas pada Kantor Kementerian Agama Kabupaten Pekalongan. Komitmen ini harus terus diinternalisasi pada pimpinan maupun pegawai.

4. Struktur Birokrasi

Struktur birokrasi berkenaan dengan pembagian kerja, wewenang dan tanggung jawab. Struktur birokrasi menjadi hambatan terkait dengan pola mutasi pegawai yang belum efektif, pembagian kerja yang belum proporsional.

Hambatan dari satuan kerja yang sudah melakukan implementasi pembangunan zona integritas dapat dijadikan pelajaran bagi satuan kerja lain, termasuk Kantor Kementerian Agama Kabupaten Pekalongan. Strategi Implementasi Pembangunan Zona
Integritas dapat diuraikan sebagai berikut:

1. Keteladanan Pimpinan

Dalam hal implementasi kebijakan publik, pimpinan harus menjadi rolemodel dalam setiap kebijakan, termasuk kebijakan implementasi pembangunan zona integritas. Keteladanan pimpinan tersebut akan menjadi contoh panutan bagi pegawai lain. Kebijakan akan lebih efektif jika menggunakan pendekatan top-down. Mengingat Pembangunan Zona Integritas merupakan amanat presiden guna mensukseskan program reformasi birokrasi.

Dalam mewujudkan hasil yang diinginkan tersebut membutuhkan perjuangan dan komitmen penuh dari unsur pegawai (mulai dari tataran pimpinan sampai bawahan). Pimpinan satuan kerja memiliki pengaruh yang besar dalam menularkan virus-virus integritas. Dibutuhkan seorang pemimpin yang benar-benar dapat mengelola dan menerapkan kebijakan strategis dalam menciptakan lingkungan birokrasi yang efektif, efisien, dan akuntabel.

Untuk membentuk karakter pimpinan yang teladan bisa dengan internalisasi nilai budaya kerja Kementerian Agama, meliputi integritas, profesionalitas, inovasi, tanggung jawab dan keteladanan. Cara lain bisa dengan menyelenggarakan kegiatan character building bagi pimpinan atau pegawai.

\section{Sumber Daya Manusia}

Sumber daya manusia merupakan aktor kebijakan. Sebagai aktor dituntut untuk memiliki kompetensi. Berdasarkan (Peraturan Menteri Pendayagunaan Aparatur Negara dan Reformasi Birokrasi Nomor 38 Tahun 2017 Tentang Standar Kompetensi Jabatan Aparatur Sipil Negara, 2017) menyebutkan bahwa Aparatur Sipil Negara (ASN) harus memiliki kompetensi. Kompetensi adalah kemampuan dan karakteristik berupa pengetahuan, keterampilan dan perilaku yang diperlukan dalam melaksanakan tugas jabatan.

Selain kompetensi, komitmen pegawai penting dalam mencapai tujuan 
organisasi, yaitu internalisasi nilai Pembangunan Zona Integritas menuju WBK/WBBM. Perubahan pola pikir dan budaya kerja pegawai sebagai bagian dari manifestasi pencegahan korupsi dan pelayanan publik yang prima merupakan hasil yang diinginkan dari proses implementasi pembangunan zona integritas.

\section{Sarana dan Prasarana}

Sarana dan prasaran juga mendukung dalam implementasi pembangunan zona integritas. Seperti ruang, peralatan dan mesin, media sosialisasi. Sarana dan Prasarana menjadi pendukung untuk memudahkan sistem organisasi yang mempersempit celah tindakan KKN dan memudahkan layanan kepada masyarakat. Pemenuhan sarana dan prasarana bisa dialokasikan anggaran yang memadai. Bisa juga dengan mekanisme kolaborasi dengan seksi yang lain dalam rangka mencapai tujuan organisasi.

4. Sosialisasi

Sosialisasi digunakan untuk menginformasikan kebijakan kepada pegawai atau masyarakat. Pilihan sosialisasi bisa disesuaikan dengan kebutuhan, mana yang dipandang lebih efektif dan efisien. Ada pilihan media sosial, spanduk informasi, maupun media elektronik.

5. Monitoring dan Evaluasi

Monitoring dan evaluasi dilaksanakan untuk memastikan bahwa implementasi pembangunan zona integritas telah sesuai dengan target yang ditentukan. Berdasarkan hasil monitoring dan evaluasi terhadap rencana kerja pembangunan zona integritas, dapat disusun rencana aksi tindak lanjut, yang kemudian disusun laporan aksi tindak lanjut. Tim monitoring dan evaluasi bisa dipilih dari pegawai yang berkompeten.

Tabel 2

Hambatan dan Solusi Implementasi Pembangunan Zona Integritas

\begin{tabular}{|c|c|c|}
\hline No & Hambatan & Solusi \\
\hline 1. & Keteladanan Pimpinan & $\begin{array}{l}\text { - Internalisasi nilai budaya kerja } \\
\text { Kementerian Agama } \\
\text { - Pembangunan karakter (character } \\
\text { building) }\end{array}$ \\
\hline 2. & Sumber Daya Manusia & $\begin{array}{l}\text { - Internalisasi nilai } \\
\text { Kementerian Agama } \\
\text { - Pemetaan pegawai }\end{array}$ \\
\hline 3. & Sarana dan Prasarana & $\begin{array}{l}\text { Melakukan kolaborasi dengan satuan kerja } \\
\text { lain untuk memenuhi sarana dan prasarana }\end{array}$ \\
\hline 4. & Sosialisasi & Memanfaatkan media offline dan online \\
\hline 5. & Monitoring dan Evaluasi & $\begin{array}{l}\text { Membentuk tim monitoring dan evaluasi } \\
\text { atas implementasi pembangunan zona } \\
\text { integritas }\end{array}$ \\
\hline
\end{tabular}

Sumber: Kantor Kementerian Agama Kab. Pekalongan, 2021 


\section{PENUTUP}

\section{Simpulan}

Implementasi Pembangunan Zona Integritas dapat dicapai dengan memenuhi semua indikator-indikator komponen pengungkit dan komponen hasil. Indikator tersebut dibuktikan dengan evidence atau Lembar Kerja Evaluasi (LKE) yang akan dinilai oleh Tim Penilai.

Selain itu tidak kalah penting adalah bagaimana implementasi pembangunan zona integritas tidak hanya sebatas slogan saja, tidak hanya pemenuhan lembar kerja evaluasi. Keteladanan Pimpinan sebagai role-model yang akan menjadi contoh teladan bagi pegawai lain. Sutau kebijakan akan lebih efektif jika menggunakan pendekatan top-down. Mengingat Pembangunan Zona Integritas merupakan amanat presiden guna mensukseskan program reformasi birokrasi. Sumber Daya Manusia sebagai aktor kebijakan juga harus memiliki kompetensi meliputi pengetahuan, keterampilan dan perilaku yang diperlukan dalam melaksanakan tugas jabatan. Selain kompetensi, komitmen pegawai penting dalam mencapai tujuan organisasi, yaitu internalisasi nilai Pembangunan Zona Integritas menuju WBK/WBBM.

Sarana dan Prasarana digunakan sebagai pendukung untuk memudahkan sistem organisasi yang mempersempit celah tindakan KKN dan memudahkan layanan kepada masyarakat. Untuk memenuhi sarana dan prasarana bisa melakukan kolaborasi dengan satuan kerja lain. Sosialisasi digunakan sebagai media penyampaian informasi kepada pegawai dan masyarakat. Monitoring dan evaluasi dilaksanakan untuk memastikan bahwa implementasi pembangunan zona integritas telah sesuai dengan target yang ditentukan. Berdasarkan hasil monitoring dan evaluasi terhadap rencana kerja pembangunan zona integritas, dapat disusun rencana aksi tindak lanjut, yang kemudian disusun laporan aksi tindak lanjut.

\section{Rekomendasi}

Hasil penelitian ini memberikan rekomendasi dalam Implementasi Pembangunan Zona Integritas Menuju WBK/WBBM, bahwa implementasi pembangunan zona integritas tidak hanya sebatas slogan saja dan hanya memenuhi lembar kerja evaluasi, namun harus diupayakan merubah pola pikir (mindset) dan budaya kerja dari masing-masing stakeholder. Strategi Implementasi Pembangunan Zona Integritas pada Kantor Kementerian Agama Kabupaten Pekalongan tersebut dapat dijelaskan sebagai berikut:

a. Keteladanan Pimpinan

Dalam hal implementasi kebijakan publik, pimpinan harus menjadi rolemodel dalam setiap kebijakan, termasuk kebijakan implementasi pembangunan zona integritas. Dalam mewujudkan hasil yang diinginkan tersebut membutuhkan perjuangan dan komitmen penuh dari unsur pegawai (mulai dari tataran pimpinan sampai bawahan). Pimpinan satuan kerja memiliki pengaruh yang besar dalam menularkan virus-virus integritas. Dibutuhkan seorang pemimpin yang benar-benar dapat mengelola dan mengimplementasikan kebijakan strategis dalam menciptakan lingkungan birokrasi yang efektif, efisien, dan akuntabel.

b. Sumber Daya Manusia

Sumber daya manusia merupakan aktor kebijakan. Sebagai aktor dituntut untuk memiliki kompetensi. Berdasarkan Peraturan Menteri Pendayagunaan Aparatur Negara dan Reformasi Birokrasi Nomor 38 Tahun 2017 tentang Standar Kompetensi Aparatur Sipil Negara menyebutkan bahwa Aparatur Sipil Negara (ASN) harus memiliki kompetensi. Kompetensi adalah kemampuan dan karakteristik berupa pengetahuan, keterampilan dan perilaku yang diperlukan dalam melaksanakan tugas jabatan.

Selain kompetensi, komitmen pegawai penting dalam mencapai tujuan 
organisasi, yaitu internalisasi nilai Pembangunan Zona Integritas menuju WBK/WBBM. Perubahan pola pikir dan budaya kerja pegawai sebagai bagian dari manifestasi pencegahan korupsi dan pelayanan publik yang prima merupakan hasil yang diinginkan dari proses implementasi pembangunan zona integritas.

c. Sarana dan Prasarana

Sarana dan prasaran juga mendukung dalam implementasi pembangunan zona integritas. Seperti ruang, peralatan dan mesin, media sosialisasi. Sarana dan Prasarana menjadi pendukung untuk memudahkan sistem organisasi yang mempersempit celah tindakan KKN dan memudahkan layanan kepada masyarakat. Pemenuhan sarana dan prasarana bisa dialokasikan anggaran yang memadai. Bisa juga dengan mekanisme kolaborasi dengan seksi yang lain dalam rangka mencapai tujuan organisasi.

d. Sosialisasi

Sosialisasi digunakan untuk menginformasikan kebijakan kepada pegawai atau masyarakat. Pilihan sosialisasi bisa disesuaikan dengan kebutuhan, mana yang dipandang lebih efektif dan efisien. Ada pilihan media sosial, spanduk informasi, maupun media elektronik.

e. Monitoring dan Evaluasi

Monitoring dan evaluasi dilaksanakan untuk memastikan bahwa implementasi pembangunan zona integritas telah sesuai dengan target yang ditentukan. Berdasarkan hasil monitoring dan evaluasi terhadap rencana kerja pembangunan zona integritas, dapat disusun rencana aksi tindak lanjut, yang kemudian disusun laporan aksi tindak lanjut. Tim monitoring dan evaluasi bisa dipilih dari pegawai yang berkompeten.

\section{DAFTAR PUSTAKA}

Ari Cahyono, D., \& Raka Suardana, I. (2021). Strategi Pembangunan Zona Integritas. E-Jurnal Ekonomi Dan Bisnis Universitas Udayana, 10(7), 574-589.

Gani, Y. (2019). Implementasi Pembangunan Zona Integritas dalam Pelayanan Publik Polri. Jurnal Ilmu Kepolisian, 13(2), 138-147.

Hanafi, A. S., \& Harsono, M. (2020). Pelaksanaan Reformasi Birokrasi dengan Pembangunan Zona Integritas pada Kementerian Perindustrian. Jurnal Informasi Dan Komunikasi Administrasi Perkantoran, 4(1), 31-37.

Indah. (2021). 54 Satker Dinilai Layak Jadi Percontohan Zona Integritas. Kemenag.Go.Id. https://kemenag.go.id/read/54-satker-dinilai-layak-jadi-percontohan-zonaintegritas-doxxj

Julia, H., Purnaweni, H., \& Priyadi, B. P. (2019). Implementasi Pembangunan Zona Integritas Menuju Wilayah Bebas Dari Korupsi Dan Wilayah Birokrasi Bersih Dan Melayani Di BBWS Pemali Juana Semarang. Dialogue Jurnal Ilmu Administrasi Publik, 1(1), 25-42.

Kadir, Y. (2018). Membangun Zona Integritas Dalam Upaya Pencegahan Korupsi Di Kabupaten Gorontalo. January.

Peraturan Menteri Pendayagunaan Aparatur Negara dan Reformasi Nomor 52 Tahun 2014 
Tentang Pedoman Pembangunan Zona Integritas Menuju WBK, 391 (2014).

Peraturan Menteri Pendayagunaan Aparatur Negara dan Reformasi Birokrasi Nomor 38 Tahun 2017 Tentang Standar Kompetensi Jabatan Aparatur Sipil Negara, 108 (2017).

Mosepa, H Andri, Agus Abdur Rahman, F. R. (2018). Pembangunan Zona Integritas di Pengadilan Tata Usaha Negara Tanjungpinang. Jurnal Hukum Peratun, 1(2), 183-202.

Peraturan Presiden RI Nomor 81 Tahun 2010 Tentang Grand Design Reformasi Birokrasi 2010-2025, 19991 (2004).

Peraturan Presiden RI Nomor 68 Tahun 2019 Tentang Organisasi Kementerian Negara, 1 (2019).

Sugiyono. (2019). Statistika untuk Penelitian. Alfabeta.

Widarti, T., \& Madalina, M. (2018). Penerapan Zona Integritas Menuju Wilayah Bebas Korupsi dan Wilayah Birokrasi Bersih Dan Melayani di Pemerintah Kota Yogyakarta. Res Publica, 2(1), 101-118.

Wilujeng, D. S., \& Pramudyastuti, O. L. (2020). Evaluasi Penerapan Zona Integritas Menuju Wilayah Bebas Dari Korupsi dan Wilayah Birokrasi Bersih Melayani (Studi Pembangunan Zona Integritas Rumah Sakit Jiwa Prof. Dr. Soerojo Magelang). Journal of Economic, Management, Accounting and Technology, 3(2), 127-135. https://doi.org/10.32500/jematech.v3i2.1286 